\title{
Johann Christian Heuson, a little-known auroral scholar of the early 18th century
}

\author{
K. Schlegel ${ }^{1}$ and S. Silverman ${ }^{2}$ \\ ${ }^{1}$ Copernicus Gesellschaft, e.V., Göttingen, Germany \\ ${ }^{2} 18$ Ingleside Road, Lexington, MA 02420, USA
}

Received: 21 April 2011 - Revised: 15 July 2011 - Accepted: 30 July 2011 - Published: 9 August 2011

\begin{abstract}
Heuson published two booklets of observations of the aurora of 17/18 February, 1/2 March 1721, and 16/17 November 1729 together with contemporary thoughts about the subject. His work characterizes him as a well-educated scholar familiar with contemporary auroral observations and theories. Heuson rejects views of the aurora as an omen or portent of divine wrath, but explains the aurora as a natural phenomenon and is thus in line with other well-known auroral scholars of that time.
\end{abstract}

\section{The author}

According to the "Taufbuch" (register of Baptism) of Frankfurt am Main, Johann Christian Heuson was baptised on 30 October 1676 (Matthäus, 2011 ${ }^{1}$ ). Since the children were baptised only a few days after birth at that time, we can be quite sure that he was born in October 1676. His father, Johann Christian Heuson (1650-1732), was originally from Ortenberg (about $40 \mathrm{~km}$ NE of Frankfurt), became in 1675 a citizen of Frankfurt and was "Schulhalter" (teacher) there. The next source about the younger Heuson is an entry "Heusen, Ioh. Christ., Francofurt", for Sommersemester (summer term) 1698 in the matriculation register of the University of Leipzig (Erler, 1909). The given names as well as the birth place of our author match, although the last name is spelled somewhat differently, which was not unusual at that time. In 1701 he published an "exercitatio theologica" about St. Pauls letter to the Colossians (Heuson, 1701) under the supervision of the well-known theology professor of Leipzig, Thomas Ittig (1643-1710). It can be judged from the title page that this work was not a doctoral thesis but most probably a work to obtain a "Baccalaureat" or "Licentiat" degree (Kohnle, 20112). In 1704 we find an entry in the matriculation register of the University of Gießen "Johannes Christianus Heusen, M.-Frankfurtanus" (Klewitz und Ebel, 1898).

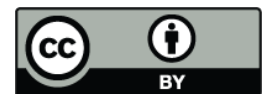

Correspondence to: $\mathrm{K}$. Schlegel

(kristian.schlegel@copernicus.org)

${ }^{1}$ Matthäus, M.: Institut für Stadtgeschichte, Frankfurt am Main, private communication, 2011.

${ }^{2}$ Kohnle, A.: Direktor des Instituts für Kirchengeschichte, Theologische Fakultät der Univeristät Leipzig, private communication, 2011.
We do not know what Heuson did between 1701 and 1704, but he must have continued his studies at Gießen which is an interesting detail, see below. The next source about Heuson is a document in the Archive of the City of Frankfurt am Main (Matthäus, $2011^{3}$ ). It is a request for a promotion to a higher rank as Gymnasium teacher dating from 1727 where Heuson stated that he had been teaching in a Gymnasium in Frankfurt/Main for 21 years. If we assume that he got into this position immediately after finishing his professional education, he must have studied in Gießen for two years, i.e. until 1706. He characterised himself as teacher "in den Studiis humanioribus insonderheit in der Oratoria theoretica et practica, wie auch Historia, Chronologia et Geographia" (humanities, especially theoretical and practical rhetoric, as well as history, chronology, and geography).

On 16 May 1707, Heuson married Maria Catharina Aulb, and after her decease in 1722, Maria Catharina Lucan on 19 May 1723. Heuson died on 5 March 1741, i.e. at an age of 65 .

Since Heuson's father was a teacher as well, and his mother the daughter of a judge in Frankfurt, we can infer that Heuson was a member of the educated class in Frankfurt. His father must have been an important figure in the church life of Frankfurt, he was precentor in the Frankfurter "Barfüßer Kirche" (church). A pamphlet of the pastor of this church Johann Daniel Arcularius (1540-1596) is dedicated to the elder Heuson, and he is mentioned in several letters of Johann Jakob Spener (1635-1705), an important theologian in Frankfurt (von Orde, 2000).

${ }^{3}$ Matthäus, M.: Institut für Stadtgeschichte, Frankfurt am Main, private communication, 2011. 
The fact that the younger Heuson first studied in Leipzig which is quite far from Frankfurt $(300 \mathrm{~km})$ and that he could afford a second period of study in Gießen (about $50 \mathrm{~km}$ north of Frankfurt), indicates that his family was probably quite prosperous. Gießen was at the turn of the 17th/18th century only the third German University (after Altdorf and Marburg) where the old Aristotelian ideas of nature were substituted by teachings based on experiments and observations (Kleinert, 2004). It could well be that Heuson went to Gießen because he was aware of the modern teaching at this University and was interested in learning more about it. On the other hand it is possible that he went there to complete his theological education with classic humanities which were a necessary requirement for a teaching position at a gymnasium which he held later. He may have been confronted in Gießen with these ideas and accepted them for his own work which reflects this modern approach (see next section). We know that besides the two booklets on aurora he published two "natural science" papers, one about a severe thunderstorm (1733) and another about a great local flooding (1739, both papers are cited in Hellmann, 1883).

\section{The first booklet about the aurora of 17/18 February and 1/2 March 1721}

This booklet has a somewhat lengthy title (see Fig. 1, including translation). From the term "jetzlaufenden Jahres" (current year) we can learn that it was published in the year of the observations, i.e. 1721. The expression "LufftGeschichte" can probably be best translated as "air affair" or "air tale". For the aurora he used the customary Latin names and the German expression "Nordschein" (literally "northern glow"). Already in the title he expressed the "naturlichen Ursprung" (natural origin) of aurora. The booklet comprises 55 pages (format $15 \times 20 \mathrm{~cm}$ ) and a plate with four copper etchings. The place of the observations is also mentioned in the title: Frankfurt am Main. The geographical coordinates are $50.1^{\circ} \mathrm{N}, 8.7^{\circ} \mathrm{E}$, the geomagnetic latitude at the time of the observations was approximately $54^{\circ}$ (Jackson, 2011 ${ }^{4}$ ). All dates refer to the Gregorian calendar, which was adopted by the Catholic parts of Germany already in 1582 , by the Protestant parts in 1700.

\subsection{The introduction}

The first 33 pages (not really entitled introduction but certainly meant as it) contain an account of contemporary natural history in terms of the classical four elements. Whereas he touches only briefly on the nature of Earth, Water and Fire, he describes phenomena related to the element Air quite

\footnotetext{
${ }^{4}$ Jackson, A.: Eidgenössische Technische Hochschule Zürich, the magnetic latitude was calculated from his magnetic field model "gufm1". private communication, 2011.
}

in detail. He distinguished between watery and fiery phenomena of the air, the former comprising for instance rain, snow, hail, clouds; the latter lightning, thunder, wind, and aurora. This is all very much in agreement with contemporary teaching dating back to Aristotle and other Greek philosophers (Gilbert, 1907). In the treatment of aurora he uses among others the term "chasma" also used by Aristotle (1931). Over four pages he then refers to several auroral observations at the beginning of the 18th century, among them the famous aurora of 17 March 1716 which is regarded as one of the first strong aurorae after the Maunder Minimum (Eddy, 1976). He cites well-known German auroral observers like Rudolph Christian Wagner (1671-1741), and Christfried Kirch (1694-1740). Heuson's description in this introduction characterizes him as a well-educated and wellinformed scholar of the Enlightenment.

\subsection{His own observations on 17 February 1721}

Heuson then describes his observation of the evening of 17 February 1721 starting at 7 p.m. when he stated that a "dim cloud" rose from the horizon and spread out in the north and northwest over the Feldberg, a local mountain. Within one hour the whole region was "darkened", but the sky was clear in other directions. At 8 p.m. he saw a yellow glow coming out of this dark cloud (Fig. 2, Heuson's notation a, $\mathrm{c}, \mathrm{g})$. It is not clear from his description if this dark cloud was a meteorological phenomenon. He talks about "Wetterleuchten" (sheet lightning) and "Blitze" (lightning bolts, zig-zag lines in Fig. 2), but did not mention any thunder. (Thunderstorms in February are rare in Germany). The yellow glow increased in intensity and subsequently formed two bright arcs stretching from west to north-east (Heuson's notation b, d in Fig. 2). Around 9 p.m. "fiery flames" came out of the arcs extending upwards like columns (f in Fig. 2). This lasted until about midnight when the forms faded away and the stars became visible again in the dark sky. This account is quite common and similar observations have been reported quite often (e.g. Fritz, 1881). Similarly common is the report of the appearance of "dark clouds" aside and between the arcs which may not be meteorological clouds. Fritz (1881) called this phenomenon "dark segment" in his famous aurora book. It could have been the "black aurora" as we term it today (e.g. Marklund et al., 1997).

\subsection{The observations of $1 / 2$ March 1721}

Heuson stated in the heading of this chapter that these observations were reported by Johann Georg Keck, also a Gymnasium teacher, thus a colleague of his. The report states that after moon set, around 10 p.m. the observer and his neighbours saw a glow which subsequently developed into three pale-yellow arcs over the town towards the east (Fig. 3). Within "half of a quarter of an hour" the arcs faded away and at the stroke of the bell at 11 p.m. nothing was left. Somewhat 


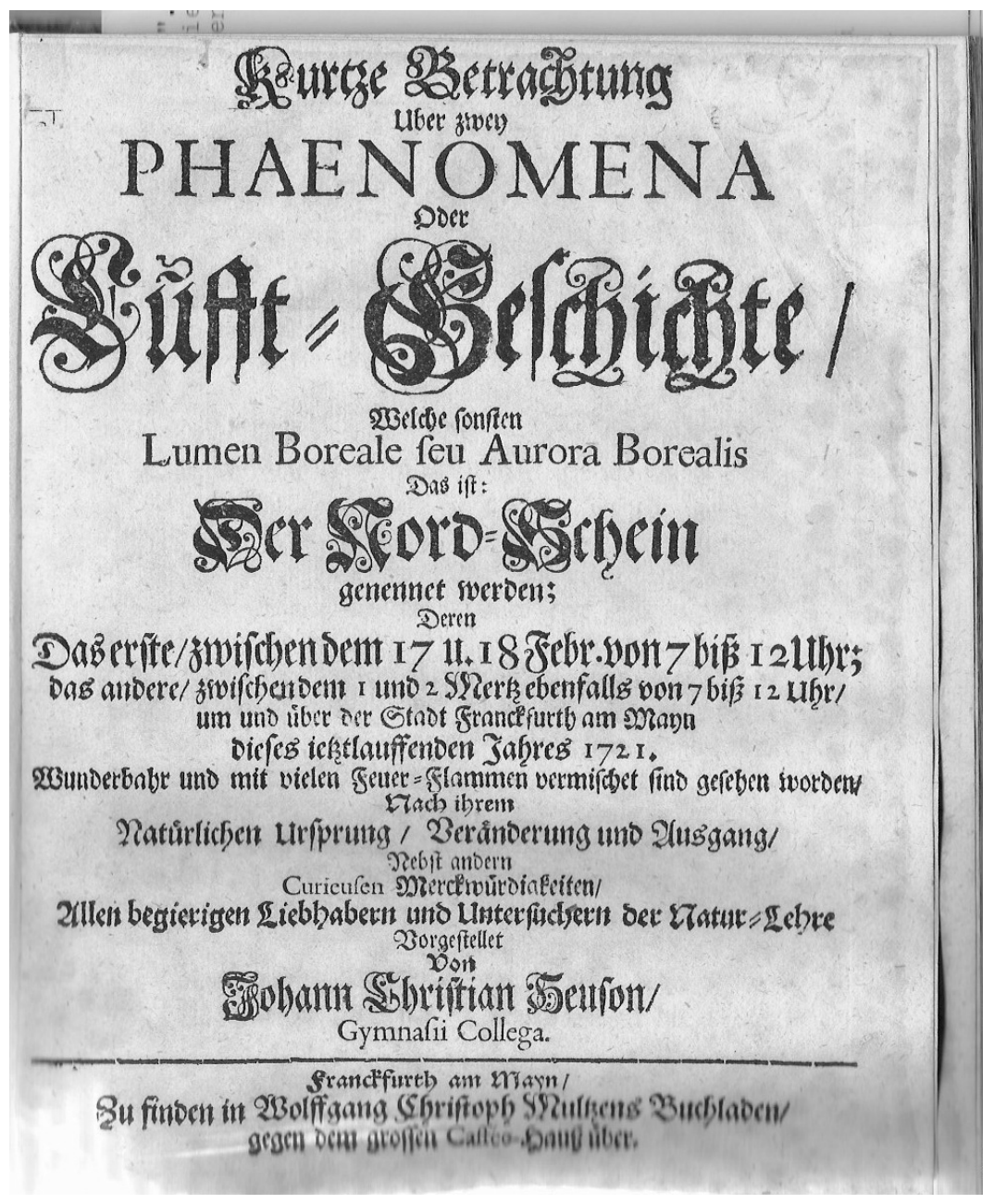

Figure 1. Title page of Heuson's first booklet. Translated:

Short reflection
on two
phenomena or
air tale/
which otherwise
lumen boreale or aurora borealis
that is:
the northern glow
are named;
from which

the first/between the 17. and 18. Febr. from 7 to 12 o'clock; the other/between the 1. and 2. March as well from 7 to 12 o'clock/ around and above the city of Frankfurth am Mayn of the current year 1721.

miraculous and with many fiery flames mixed have been observed after their natural origin/changes and end/ together with other curious oddities/

all eager enthusiasts and researchers of natural science presented by Johann Christian Heuson/ Gymnasium teacher 


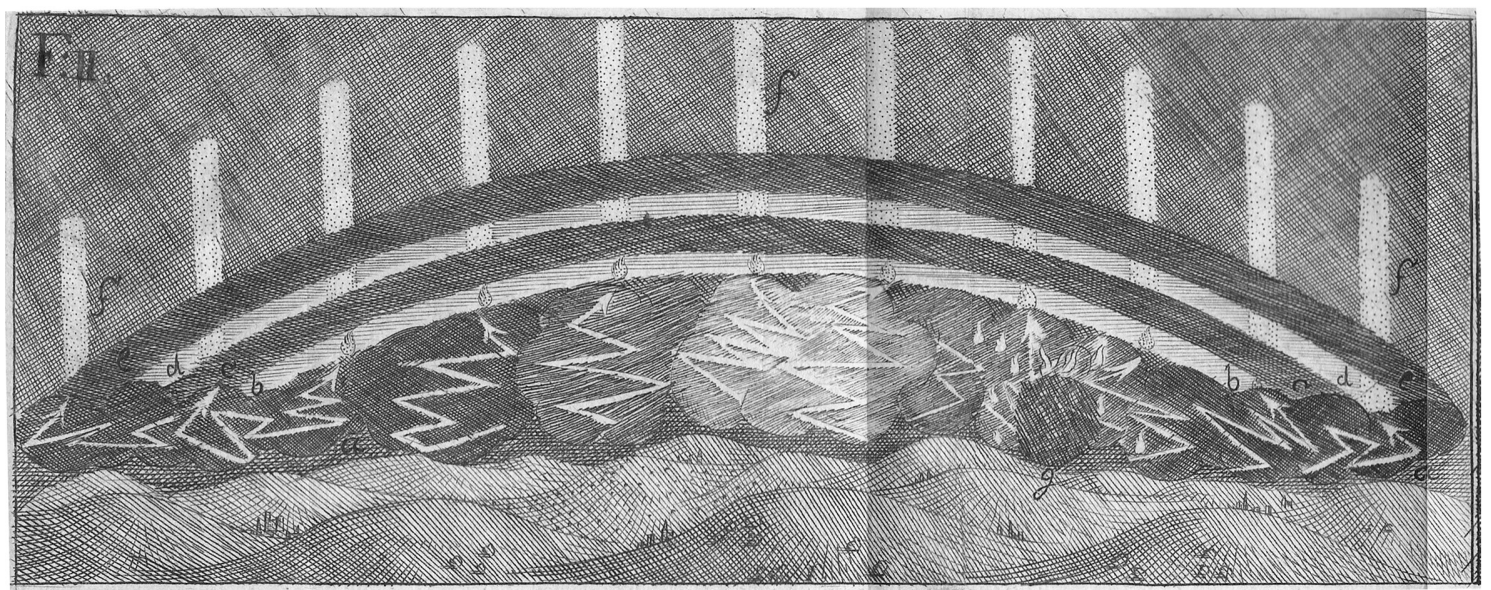

Figure 2. Copper plate of Heuson's observation on 17/18 February 1721. The small letters refer to his description.

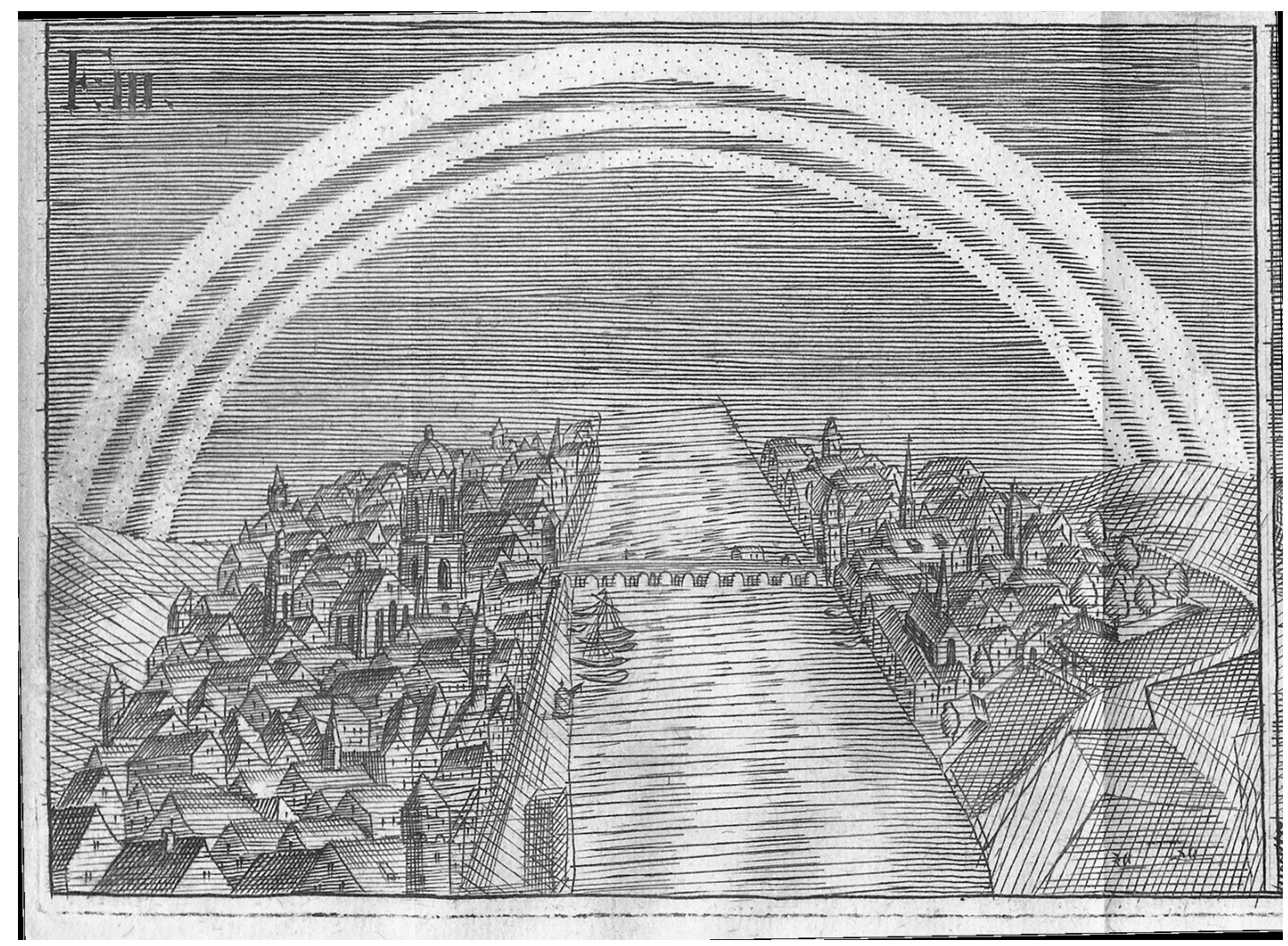

Figure 3. Copper plate of the observation on 1/2 March 1721.

later (no time given) however, he saw red flames moving upwards towards the east. Keck's neighbours reported a thin smoke and an audible hiss associated with the flames. The flames disappeared around midnight but a glow remained until 2 hours in the morning. It should be remembered that reports about noises from aurora prevail until today (for a review of auroral audibility, see Silverman and Tuan, 1973).
Heuson then cites reports of other observations from the same time at other locations in Europe. He used the expression "in Briefen wurde berichtet" (it was reported in letters) several times which indicates that he kept correspondence with other aurora observers. 


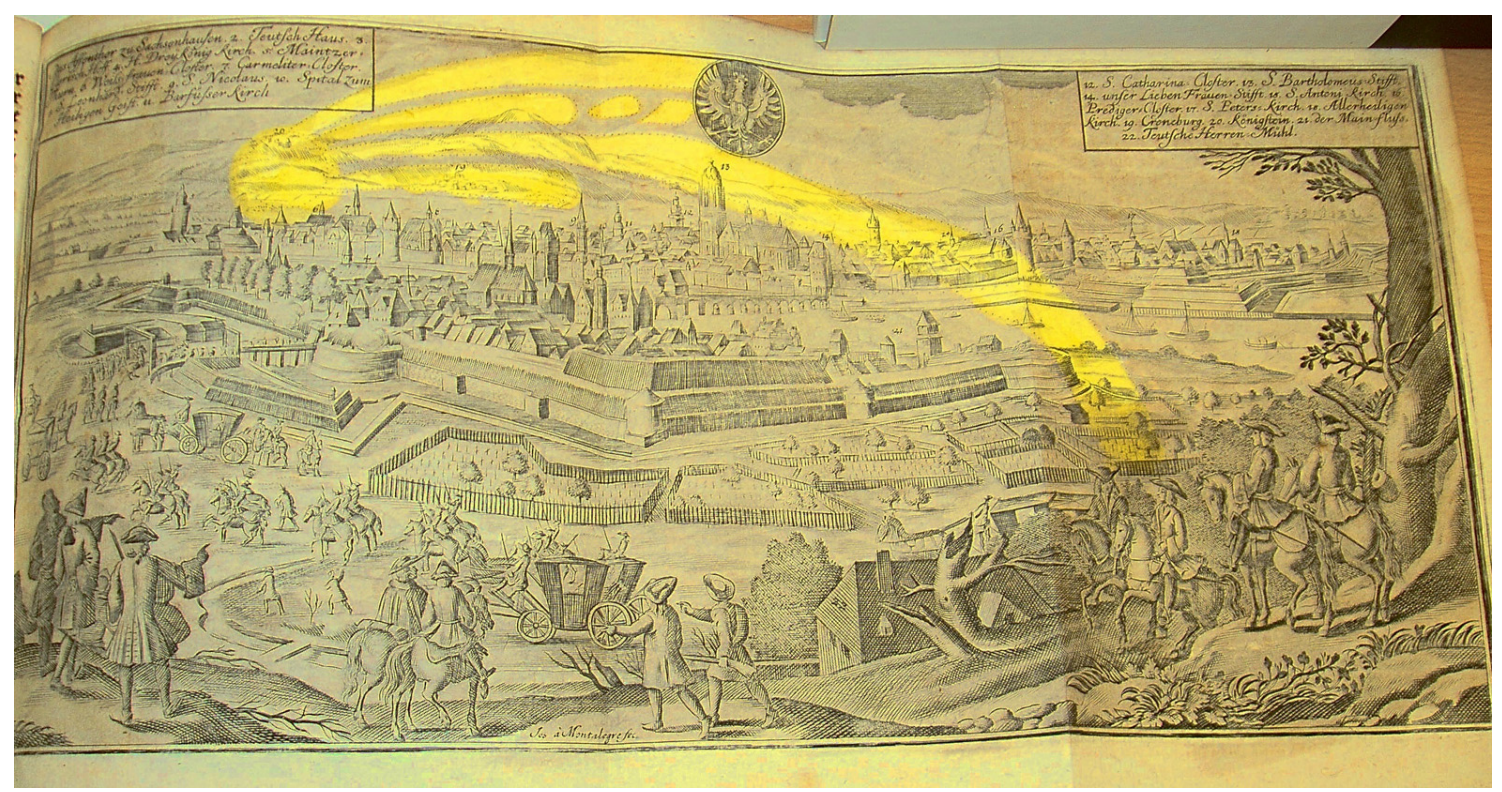

Figure 4. Copper plate of the observation on 16 November 1729. This illustration is remarkable since it is printed in two colours (gray-scales and yellow). It is said in the title page of the booklet "auf Kupfer mit deutlichen Farben delineiret" (on a copper plate marked with clear colours). So Keck may have used an existing copper plate of the city and drew the arcs on it in yellow.

Fritz (1873) notes observations of the aurora of 17/18 February from Switzerland, Hungary, Germany, Poland, France, England and Sweden. An observation from Dublin, Ireland is also noted by Lowe (1870). For the aurora of 1 March Fritz (1873) notes observations from Switzerland, Germany, Poland, Ukraine, Netherlands, France and Sweden.

\subsection{Thoughts about aurora}

The last seven pages of Heuson's booklet are entitled "Gedanken über den Nordschein" (Thoughts about the northern glow). At length he tried to persuade the reader with various arguments that the aurora is not an omen or portent but a natural phenomenon. He argued that it is "ein Meteoron, das ist ein in der Lufft erzeugter Körper" (a meteoron, i.e. a material generated in the air). This is not really his own idea but was a contemporary conception which prevailed well into the 19th century (e.g. in A. von Humboldt's Kosmos, 1845). Heuson also explained that the aurora must be "self illuminated" and did not receive its light from the Sun or Moon. Heuson judged the height of the arcs as about half a mile, but then had difficulties in explaining the simultaneous sightings at other places in Germany. He further proposed that the light is caused by "humid, dry, sulphurous and nitrous mist", which is "thin" in contrast to lightning strokes where these substances are "thick". He thus called the aurora an "imperfect lightning stroke". The burning mist is driven upwards which causes the audible hiss, as well as a smell of burning, as reported by many observers. Towards the end he tries to disprove the old ideas of the aurora as an omen or portent with theological arguments. He concludes that God fearing Christians should be delighted that the heavens demonstrate the glory of the Lord.

\section{The second booklet about the aurora of 16/17 November 1729}

This booklet with the (abbreviated) title: "Liechter und Feuer*Zeichen welche... Nord*Schein... gehalten werden." (lights and fire*signs which... are regarded... as northern glow.), is much shorter, it consists of only 11 pages and two copper plates, in the same format as the first booklet. The title page states that the observations have been recorded by Joh. Georg Keck, the same colleague who contributed to the first booklet, but that the included assessments have been "aufgesetzt und zum Druck befördert" (drafted and sent to print) by Joh. Christian Heuson and Joh. Georg Keck. The title page also gives the date: "zwischen (between) dem 16. und 17. Novemb." and the location "Stadt Frankfurt am Mayn".

\subsection{Keck's report}

After a two-page introduction in which Keck criticises the "prodigium" conception of the aurora as an omen or portent so far associated with atmospheric phenomena, he gives an account of the observed aurora. At 6 p.m. a fire-red cloud rose in the west and south west sky which was so bright that the eyes were blinded. It moved to the north west and 
brightened even more around 8 p.m. It looked like a bright sphere from which many bright arc rays extended towards the south east over the whole city (see Fig. 4). The arc faded away soon and after three quarters of an hour the whole phenomenon was gone and the sky appeared clear and starry.

A second display appeared later and consisted of many straight rays shooting upwards together with "thin white smoke" and "small red flames". Around midnight the sky in the northeast became red as if "a fire was burning" and Jupiter and stars from several constellations were visible through this cloud. Keck then reported readings from his thermometer, barometer and hygrometer and related them to the weather of the following morning. But he cautiously stated "Ob nun dieses obigen Phenomenis und dero Würckung zuzuschreiben, will ich anderen überlassen zu beurteilen" (If this \{weather\} is caused by the above reported phenomenon, I will leave to others to judge). It should be remembered that a connection of aurora and weather was assumed for a long time, even Fritz (1881) devoted a whole chapter of his book to this topic.

\subsection{Heusons comments}

On the following three and a half pages Heuson described observations of the same event from other locations. It is specifically stated in the heading of this section that it was written "von mir (by me), Joh. Christian Heuson". He mentioned reports from Leipzig, Leyden (Holland), Paris, Duisburg (190 km NW of Frankfurt), Creutz-Wertheim (70 km SE of Frankfurt), Warsaw (Poland), and Wittenberg (340 km NE of Frankfurt). In two of these reports he quoted letters of friends, for the other five no source is given.

In the last chapter ( 2 pages) headed "Geneigter Leser" (kind reader) Heuson stated again that he regarded this phenomenon as an "incomplete lightning... without thunder". $\mathrm{He}$ characterises the "castles, houses, mountains, rivers, animals and fishes" which people saw in the sky as pure imagination. He continued that the aurorae observed since 1721 (his first observation) have not heralded bad and dangerous events and concluded with a praise of the Lord.

In addition to the locations noted by Heuson the aurora of 16 November 1729 was observed at other sites in Germany and Holland, in France, Sweden and Russia. At Leipzig and Berlin it was seen for the entire night, and in Berlin over the entire sky (Fritz, 1873). The aurora was also observed in Boston, Massachusetts, USA, where it was described as very bright, and in Rhode Island, USA, where it surprised the inhabitants (Green, 1885).

\section{Concluding remarks}

Auroral catalogues, such as those of Fritz (1873) and Angot (1897) provide us with the date and location (more or less precisely), and, occasionally, a remark such as "bright", "covered the whole sky", or "reddish". Books about the aurora provide us with a generalized view of the time and geographical variations of the aurora. Descriptions of the aurora from a specific time and place, such as in the Heuson publication, provide us with a better sense of the temporal behaviour, and the dynamics of the aurora. This is especially true of early observations of the aurora, such as those in the eighteenth century.

Catalogues and books about the aurora also do not tell us anything about the background of the observer. He may be well known, as Anders Celsius (1701-1744), or Jean-Jacques d'Ortous de Mairan (1678-1771) were, but more often he may have been an amateur, a lesser known scientist. What were the characteristics of these observers? Our knowledge of the frequency of auroras in these early days depends to a substantial extent on such amateurs, and we need to know more about their histories and characters. In the present case we know something about his background, his education, and the change in his outlook over time. We know, furthermore, that Heuson's education began, at Leipzig, at a time when the emphasis in German universities was on preparation for religious teaching, and science was taught from an Aristotelian perspective without reference to observation. And we learn, again from Heuson's intellectual development and his attendance at the University of Giessen, that this was a period when science moved from Aristotelian texts to observation, Heuson, then, represents a transition from a science based on theological and classical texts to observation.

It should be stressed that all the ideas about the aurora that Heuson presented in the first booklet were contemporary concepts. The height of the arcs of about half a mile and the term "imperfect thunderstorm", are already mentioned in Professor Christian Wolff's (1679-1754) famous public lecture, which he presented after the great aurora of 1716 at the University of Halle/Saxony and which was subsequently published (Wolff, 1716). This account was widely distributed and Heuson probably had a copy. Thus Heuson apparently agreed with this well-known German scholar, and was - with his natural explanations - also in line with the aforementioned R. C. Wagner and C. Kirch, and with the British astronomer Edmond Halley (1656-1742). It should be noted that the aurorae of 17/18 February, 1/2 March 1721, and 16/17 November 1729 have been observed in many places over Europe and are well documented. Fritz (1830-1893) cited Heuson by name in his famous catalogue (Fritz, 1873). 
Edited by: T. V. Kuznetsova

Reviewed by: D. M. Willis and another anonymous referee

\section{References}

Angot, A.: The Aurora Borealis, New York, D. Appleton and Company, 1897 (translation of the original French version published in 1895).

Aristotle: Meteorologica, Book 1, Transl. by E. W. Webster, Oxford, 1931.

Eddy, J. A.: The Maunder Minimum, Science, 192, 1189-1202, 1976.

Erler, G. (Ed.): Die jüngere Matrikel der Universität Leipzig 15591809, II. Band, Giesecke und Devrient, Leipzig, 1909.

Fritz, H.: Verzeichnis beobachteter Polarlichter, Wien, 1873.

Fritz, H.: Das Polarlicht, Leipzig, 1881.

Gilbert, O.: Die meteorologischen Theorien des griechischen Altertums, Teubner, Leipzig, 1907.

Green, S. A.: Remarks on the Early Appearance of the Northern Lights in New England, John Wilson and son, Cambridge, 1885 (Reprinted from the Proceedings of the Massachusetts Historical Society, 1885), citing the New England Weekly Journal for November 10, 1729.

Hellmann, G.: Repertorium der Deutschen Meteorologie, Verlag W. Engelmann, Leipzig, 1883.
Heuson, J. C.: Residuo passionum Christi quod Paulus in carne sua ecclesiae causa cum gaudio adimplevit, Facultatis Theologicae sub praesidio D. Thomae Ittigii, Lipsiae, 1701.

Kleinert, A.: Naturwissenschaft und Mathematik in Gießen im 18. Jahrhundert, in: Form, Zahl, Ordnung, Studien zur Wissenschafts- und Technikgeschichte, edited by: Seising, R., Folkerts, M., and Hashagen, U., Verlag Steiner, Stuttgart, 563576, 2004.

Klewitz, E. und Ebel, K.: Die Matrikel der Universität Gießen 1608-1707, J. Rickersche Verlagsbuchhandlung, Gießen, 1898.

Lowe, E. J.: Natural Phenomena and Chronology of the Seasons, Bell and Daldy, London, 1870.

Marklund, G., Karlsson, T., and Clemmons, J.: On low-altitude particle acceleration and intense electric fields and their relationship to black aurora, J. Geophys. Res., 102, 17509-17522, 1997.

Silverman, S. M. and Tuan, T. F.: Auroral audibility, Adv. Geophys. 16, 155-266, 1973.

von Humboldt, A.: Kosmos, Vol. 1, Cotta'scher Verlag, Stuttgart und Tübingen, p. 198f, 1845.

von Orde, K.: Philip Jakob Spener und sein Frankfurter Freundeskreis, in: Von der Barfüßer Kirche zur Paulskirche - Beiträge zur Frankfurter Stadt- und Kirchengeschichte, edited by: Fischer, R., Waldemar Kramer, Frankfurt/Main, 2000.

Wolff, C.: Gedanken über das ungewöhnliche Phoenomenon, Halle, 1716. 